\title{
Conference Paper
}

\section{Ongangen (Wisdom): Women's Means of Overcoming Troubles as Depicted in Maranao Folktales}

\section{Eugenia A. Velasco}

Faculty, Mindanao State University, Marawi City, Philippines

Ph.D English (Literary Studies)

Silliman University, Dumaguete City, Philippines

\section{Abstract}

This paper utilized feminist analysis to find out how women characters in the selected Maranao folktales used ongangen or wisdom to solve their problems. Specifically, this study aimed to find out (1) the roles of women as depicted in Maranao folktales; (2) their struggles; and (3) their means of maintaining balance to overcome such struggles.

Corresponding Author: Eugenia A. Velasco eanonas@yahoo.com

Received: 23 April 2018 Accepted: 8 May 2018 Published: 4 June 2018

Publishing services provided by Knowledge

(c) Eugenia A. Velasco. This article is distributed under the terms of the Creative Commons Attribution License, which permits unrestricted use and redistribution provided that the original author and source are credited.

Selection and Peer-review under the responsibility of the IRCHE 2017 Conference Committee.

\section{G OPEN ACCESS}

The analysis revealed that Maranao women played important roles in the Maranao society, especially so, if they held royal titles. They performed social functions inside their clan. However, these women still struggled against discrimination within their own societies as well as against stereotyping once they came out from the confines of their family and tribe. In the folktales, the Maranao women used ongangen to try to overcome their struggles. Doing so allowed them to keep their balance thus they were able to face their challenges more serenely and confidently. Such depiction provides another dimension to the common image of Maranao women who merely stay at home taking care of the children and being submissive to the husband.

Keywords: folktales, Maranao, Maranao women, ongangen, overcoming troubles

\section{Introduction}

The Maranaos are one of the three main Muslim groups already a unit before the arrival of Islam in the island. They mostly live in the interior portion of western Mindanao around a lake. The Maranao term for lake is "lanao", thus the term "Maranao" refers to the people of the lake [1].

The Maranaos as a unit have their own set of beliefs and way of life. They are known to be superstitious just like other ethnic or tribal groups in the Philippines. Madale (1976) observed that "religion cannot completely erase local customs, practices, and beliefs even if these are against such religion." They also follow certain courtship and 
marriage practices that are unique and interesting. Moreover, they are widely known for their sophisticated weaving and wood metal craft [2].

The Maranao society adheres to the patriarchal system: males are at center stage occupying highest positions. They are given higher valuation and wider exposure than the females in preparation for their future societal roles. In this respect, maleness and wisdom are the utmost prerequisites of manhood in Maranao society. This ideal is celebrated in the Darangen, the Maranao epic song which encompasses the wealth of the people's knowledge about their history, the tribulations of their mythical heroes, customary law, standards of social and ethical behavior, notions of aesthetic beauty, and social values.

Although mainly patriarchal, Maranao society nonetheless gives its women their due importance and assigning them societal roles to play aside from being a grandmother, mother, daughter, and sister. Such roles are reflected in the Maranao oral literature specifically its folktales.

Knowledge by other Filipino groups of Maranao customs and beliefs is at best sketchy. Those far from Mindanao either are totally unfamiliar with the group or have negative impressions about them due to hearsays. Thus, this study aims to help provide a better understanding of Maranao society and its people.

This paper focuses on how the Maranao concept of ongangen, meaning wisdom, is utilized by the women to surmount their day-to-day challenges as shown in the five selected Maranao folktales. Specifically, it intends to determine (1) the roles of Maranao women as depicted in the folktales; (2) the daily struggles of the Maranao women; and (3) their means of maintaining balance despite their struggles and/or challenges.

The Maranao concept of ongangen is similar to the Navajo concept of "hozho" or, more completely, "hozho: walking in beauty". For the Navajo people, hozho represents synthetic and living description of what life on earth should be, from birth until death at an old age. Hozho is the shorthand of the phrase sa'ahnaaghaiibik'ehhozho, which are actually "two distinct phrases that together form a unity". The whole phrase means a model of balance in living which encompasses health, long life, happiness, wisdom, knowledge, harmony, and order [3]

Lincoln (2007) maintains that hozho is the ideal life for the Navajo people - a life that is long and filled with harmony, peace, happiness, and beauty [4]. The concept was used by the American Indians as they struggled against the Europeans when the latter invaded the "New World". More particularly, according to Gunn Allen (1992), it was utilized by the American Indian women in trying to deal with the effects of colonization: 
These women struggle on every front for the survival of their children, their people, their self-respect, their value systems, and their way of life. On their journey of surviving, they continue living and even come to the point of surviving war and conquest, colonization, acculturation, assimilation, beating, rape, starvation, and all sorts of hardships [5].

Many Navajo dealt with colonization negatively: some became alcoholics and addicts; others abandoned their children and their elders; while still some others became violent, insane, or committed suicide. However, there were those who tried to face their situation with equanimity and so wrote songs and poems or painted and drew taking strength from the saying, "We walk in beauty. Let us continue"[6].

Smith (2011) in her book's Introduction explains "walking in beauty":

I focus on the real value that is deposited into a woman to persevere through life despite hardships, happiness, struggles, love, failures, disappointments, and success. We as women must maintain balance and have structure to nurture us. As we discover our quality, we must strive harder to guard the hidden treasure that was deposited into us not to obtain worth, but to appreciate how valuable we are as individuals [7].

The concept of ongangen is reinforced through the use of cultural feminism as an analytical approach. For Bressler, (2007) cultural feminism asserts that "personality and biological differences exist between men and women". Its main belief is that "women are inherently and biologically 'gentler' and 'kinder' than men". As such, these women's ways should be highlighted and celebrated because in the eyes of the cultural feminists, women's ways are better than men's [8].

Such description of women comes true with the Maranao women. As they go through life, meeting challenges is inevitable. The study of Carlos and Cuadra (2014) uses the term resilience to describe Muslim women's ability to regain their shape after going through crises or difficulties as they closely follow their family traditions and practices. Muslim women in the first place are believed to be good followers of their religious and cultural practices and following the said practices entails challenges. One that challenged much the Muslim women is the arranged marriage [9]. Despite of this, they are still able to cope and do well in life despite of having to face many struggles.

Stories about how Muslim women remain in shape and how they empower themselves despite of discriminations and prejudices really become so inspiring. According to El-Haddad (2012) as cited by Carlos and Cuadra (2014), "Palestinian women face their own unique challenges; they face an enormous burden in terms of not only raising their 
families, but rehabilitating those families in the aftermath of Israeli assaults like Cast Lead and the on-going blockade. Palestinian women were also increasingly becoming the breadwinners in their families" [10]. The said women in this situation, are playing multiple roles and responsibilities. But despite the challenges, they still continue and take their responsibilities as a wife, a mother and a Muslim woman.

Similarly, the study of Rogers (2000) explores how midlife women found the strength and resilience that enabled them to rebound and grow as they negotiated significant life challenges in their marriage, and with their children, parents, careers, and health [11]. The study reveals that even for the challenges these women met in their midlife and in their marriage they remain in shape for they use core beliefs that facilitated how they made meaning of their struggle and influenced their response to their challenge. They also stress the importance of having connectedness and relationships to make them strong enough as they face challenges.

\section{Objectives of the Study}

This paper focuses on how the Maranao concept of ongangen, meaning wisdom, is used by the women to surmount their day-to-day challenges as shown in the five selected Maranao folktales. Specifically, it intends to determine (1) the roles of Maranao women as depicted in the folktales; (2) the daily struggles of the Maranao women; and (3) their means of maintaining balance despite their struggles and/or challenges.

\section{Materials and Methods}

This paper employs feminist analysis to find out how women characters in the five selected Maranao folktales published in The Mindanao Art and Culture Number One The Agamnaiyog Folktales, used ongangen or wisdom to solve their problems. The analyses of these folktales have been guided by the following questions: (1) What are the roles of women as depicted in these folktales? (2) What are their struggles? and (3) How do they maintain balance to overcome such struggles?

\subsection{Folktale synopses}


"Tingting a Bolawan and her Wicked Aunts" is about Tingting a Bolawan, the only daughter of Solotan and Bai sa Agamaniyog and how she and her three brothers, Radiya Bagaran, Radiya Mangandiri, and Radiya Mangawarna, survived and escaped the wickedness of their mother's sisters, Potri Bonso, and Matagbabay. After birth, the siblings were thrown by their aunts to the river telling their sister, Bai sa Agamaniyog, that her children have died during her labor. However, the children survive and manage to live on their own by the shore. Potri Bonso and Matagbabay later notice these children and realize they might be their own niece and nephews. They devise another plan to harm the latter. Every time the three brothers are out, they visit Tingting a Bolawan in her house and try to poison her mind by telling her if she couldn't have things like "bentola a bolawan" (miniature golden cannon) her beauty will be useless and that she should also have "surod and salday a bolawan". Tingting a Bolawan, unaware of her aunts' malicious intent, then expresses desire to own these things endangering her brothers' lives who get magically imprisoned in a big tree while attempting to procure the items. In the end, Tingting a Bolawan sets her brothers free and, eventually, they are all reconciled with their father and mother.

\subsection{Tiny bird}

Tiny Bird is about the couple Lokes a Mama and Lokes a Babay who are in the habit of setting bird traps late in the afternoon and visiting these early the next morning. Since Lokes a Babay cannot climb trees, her trap is always set on the ground. One day, Lokes a Mama cheats his wife by exchanging their traps when he sees that her trap got a big fat deer while in his trap, only a tiny bird was inside. Lokes a Mama cheats again but his wife keeps silent although she knows about it. One night, she dreams that her pet bird would lay precious stones if fed with palay every day. She does it without telling her husband. Her husband continues trap-cheating her until she decides to divorce him. She builds her own torogan (royal house) in a nearby settlement. When Lokes a Mama hears of her good fortune, he wants to reconcile with her but Lokes a Babay refuses.

\subsection{A lesson for the sultan}

The story is about Solotan sa Agamaniyog and Ba'i sa Agamaniyog, a wealthy couple who owns almost half of the land in Agamaniyog. They have been quarrelling over Lokes a Mama and Lokes a Babay's misfortune. Solotan sa Agamaniyog blames Lokes 
a Mama but Ba'i sa Agamaniyog blames Lokes a Babay for her laziness and inability to support her husband. Their arguments lead the couple to separate. The Solotan goes to live with Lokes a Babay in her torogan, while Ba'i goes to live with Lokes a Mama in the nearby forest. Ba'i sa Agamaniyog tries to prove to the Solotan that Lokes a Mama's failure to be a good provider is Lokes a Babay's fault. Lokes a Mama gradually made Ba'i rich and becomes a renowned while the Solotan loses everything because of Lokes a Babay.

\subsection{Empty bags, bitter rice}

The story tells of the separation of the Solotan sa Agamaniyog and Ba'i sa Agamaniyog because of jealousy. The Sultan thinks that his wife is in love with Lokes a Mama when she expresses her pity towards Lokes a Mama and Lokes a Babay who are very poor. He asks his wife to leave the torogan and take Lokes a Mama as her husband while he takes Lokes a Babay. The Ba'i gets hurt but still follows the order. With so much weeping, she leaves the torogan but before leaving she tells her husband that she has always been faithful to him. When the Ba'i and Lokes a Mama are able to settle in a good place, she tells him to do his best so that in the future the Sultan will instead be following him carrying his bags for him. Ba'i encourages Lokes a Mama to endeavour to have a better life and helps him by weaving baskets and stuff. She also saves some of their earnings. Little by little their savings increase and their livelihood improves. On the other hand, the Solotan's wealth decreases because Lokes a Babay is very lazy, and his land is stricken by famine. Ba'i sa Agamaniyog's last words to her former husband come true when the latter goes to her place to buy palay. The story ends with the Solotan feeling great shame and sadness because of his misfortune.

\subsection{The wanderings of Radiya Mangandiri}

Radiya Mangandiri sets out to search for the woman destined to be his wife. While searching, he saves a beautiful maiden named Potri Gonong Lidang from the tarabosaw, a man-eating monster. Potri Gonong Lidang is actually a lost princess (daughter of Sultan Bandiyarmasir). Her father's men have long been searching for her but they have, so far, been unsuccessful until they chance upon her resting with Radiya Mangandiri after being attacked by the tarabosaw. She is brought to her father's torogan while Radiya Mangandiri is left sleeping in the cogon hut. She tells her father how she 
was rescued by the young man. The sultan then orders his men to bring to him Radiya Mangandiri to be rewarded.

Potri Gonong Lidang has a cousin named Potri Intan Tiyaya, also a princess. Having heard some merriment, Potri Intan Tiyaya goes to her cousin's torogan to investigate and sees Potri Gonong Lidang. Radiya Mangandiri, on the other hand, sees Potri Intan Tiyaya and realizes that he is the woman in the portrait left by his father, the Sultan sa Agamaniyog, whom he is destined to be married. However, Potri Intan Tiyaya has already received a marriage proposal from the prince of Bandiyarkorom. The prince challenges Radiya Mangandiri to a contest, with the winner marrying Potri Intan Tiyaya. Radiya Mangandiri wins so he marries Potri Intan Tiyaya.

\section{Results and Discussion}

\subsection{Roles of Maranao women in their society}

In spite of the inequality between the Maranao women and their male counterparts, the former do hold titles and positions in their community although first and foremost, "it is the home where she plays the ethical role of a daughter, a mother, an aunt, and a kindly grandmother" (Saber, 1979) [12].

Ba'i sa Agamaniyog, for instance, in the stories, A Lesson for the Sulton and Empty Bags, Bitter Rice holds the title (grar) "ba'i", the female counterpart of "sultan". Ba'i lives in the torogon (royal house), the symbol of rank, status, and power among the Maranaos and is the highest ranked among women in the community. Manalisig (1979) states that "Maranao women assume varied titles and statuses in the traditional sultanate...The title of Ba'i a labi is the feminine equivalent of the title Sultan or Datu" and she is expected to uphold the honor and prestige of the community and to perform her functions as stated in their customary laws [13].

In the story, Empty Bags, Bitter Rice, after a few years of the Ba'i leaving Agamaniyog to live with Lokes a Mama (lokes means old, mama means man), the land experiences famine:

Finally, famine (toon) came to Agamniyog, because farmers had fewer, since Ba'i sa Agamniyog left the place. This was because she was not there to give them advice [14].

This suggests that she played an important role in Agamaniyog aside from being the counterpart of the Sultan. When a Maranao woman becomes an adult, "the menfolk 
consult her on important matters of family and community affairs, more so if she holds the female title (grar) and is known for her wisdom"(Saber, 1979) [15]. Since she is expected to play that role and, at the same time, serve as the people's inspiration not only as the female counterpart of the Sultan but also because of her wisdom, the farmers are no longer encouraged to do their best to make the land productive because their inspiration is gone.

Tingting a Bolawan and Potri Godong Lidang, on the other hand, are princesses. They are daughters of Sultans and Ba'is. Tingting a Bolawan, in freeing the people imprisoned in the gindolongan tree and whose eyes are pulled out and placed in the omoy, an earthen water vessel, is told "becouse you hove freed us you will be our queen and your brothers our princes" [16]. She becomes their savior and inspires the people with her bravery, wisdom, and determination.

Potri Godong Lidang is also a princess although she has been away from her parents for a long time. She suffers so much; nevertheless, when she is already safe and back in the torogan, she wields authority. Even Radiya Mangandiri listens to her. When she tells him, "I know that you are looking for something. I must tell you that you would not find it if you do not come with me. I shall be of great help to you"[17]. Here, she serves as an instrument to end Radiya Mangandiri's wanderings. Through her wisdom, Radiya Mangandiri finds the woman meant to marry him.

Lokes a Babay, in contrast, is an ordinary woman and already of age (Lokes means old/mature but she does not let these deter her starting her life over again. She states:

I can no longer stand the way you treat me as a wife. I know you have been cheating me. For this reason, I accept your suggestion to divorce me. From now on, we will live separately without disturbing each other's lives [18].

In Maranao society, even if a woman does not hold any title but already an adult known for her wisdom, she would be looked up to by the people, with the menfolk seeking her advice or consulting with her regarding important family and community affairs (Saber, 1979) [19]. Lokes a Babay is seen as an independent woman whose fortune from the tiny bird has allowed her live like royalty despite not having a royal title: "she built a torogan in a nearby settlement [and] had guards and slaves to serve her" [20]. 


\subsection{Struggles of the Maranao women}

The selected folktales portrayed Maranao women having struggles/challenges within the confines of their own culture and society. These struggles are still the same today as in the past. According to tradition, a Maranao girl is brought up in the strictest manner. She has a whole set of grandmothers, aunt, and elderly ladies, who teach her what and how to do things. In addition, her mother is tasked with the responsibility of transmitting to her the unique customs and traditions that will make her the Maranao girl she ought to be (Plawan, 1979) [21]. Despite such guidance and teachings, the Maranao woman is not spared from the difficulties that life may bring.

In the five folktales analyzed, the women characters struggled in various ways. Tingting a Bolawan struggles to survive right after birth when her two aunts threw her to die in the river, together with her three brothers. Growing up, she is confined inside the house by her three brothers, not exposed to the outside world. Her aunts take advantage of her naivety/gullibility easily manipulating her to make frivolous demands from her loving brothers: get the "bentola a bolawan" (miniature golden cannon); and then the salday and surod a bolawan lest her beauty would be diminished.

She is demanding these things, unknowingly endangering her brothers' lives, to feed her vanity. In a sense, keeping appearances is important to Maranao women who grow up within a tradition of both modesty and proper grooming although this might later on become a weakness. For instance, before wearing any new blouse or clothing, a Maranao girl always says to herself: "These clothes will bring me happiness." (Plawan, 1979) [22]. Thus, Tingting a Bolawan, after being told she should have magical things so as not to waste her beauty, obsesses in acquiring the salday and the surod a bolawan becoming deaf to her brothers' warnings endangering their lives in the process.

Meanwhile, Lokes a Babay in Tiny Bird is maltreated by Lokes a Mama, her husband but after a while she stands up to him: "I know you have been cheating me. For this reason, I accept your suggestion to divorce me. From now on, we will live separately without disturbing each other's lives" [23]. Choosing to remain silent becomes a strategy for her so she could follow her dream which could potentially bring her fortune.

On the contrary, her silence shows her being tied to her husband as is commonly expected in Maranao society. Such practice is also depicted in A Lesson for the Sulton and Empty Bag, Bitter Rice. The Ba'i and the Sultan sa Agamaniyog in both stories argue about the misfortune of another couple. Their argument results in a serious quarrel and the Sultan decides for both of them to go on an arranged marriage with the said couple, Lokes a Mama and Lokes a Babay, no matter how absurd this may seem. 
This situation shows that a man cannot allow a woman to step on his ego. Women are in many ways submissive to their male-counterparts inasmuch as they are made to believe that a woman's primary responsibilities are to look after the family and manage the home. Once married, they have to follow the wishes of their husbands. For the Maranao woman, being submissive extends to agreeing to an arranged marriage, negotiated by her family, while still very young. Though unprepared to face the responsibilities of being a wife, she cannot protest because this is customary for their tribe.

Sultan and Ba'i sa Agamaniyog and Lokes a Mama and Lokes a Babay exchanging partners, in a sense, is also an arranged marriage. Ba'i sa Agamaniyog is a princess who was kept by her parents in their lamin (tower) when young. She was not seen by people except by her parents, siblings and her maids. She was not exposed to even minor household chores. But the Ba'i exposes herself to hard physical labor to augment Lokes a Mama's earnings as a means of showing him her support:

Ba'i sa Agamaniyog then wove the rattan into baskets and other things that could be sold in the market. She gave the finished products to the children to sell $[24]$

Bai's own efforts and support of Lokes a Mama improve their living condition exponentially while the Sultan, her former husband, loses his wealth.

In the case of Potri Godong Lidang, her primary struggle is being away from her parents, the Sultan and the Ba'i sa Bandiyarmasir who had been looking for her for a long time. This separation brings about her secondary struggle - the cruelty of the tarabosaw: "I'll just hope that every day the tarabosaw (a man-eating moster) can get some food...she is reserving me for the time when she cannot find food ...."[25].

Traditionally, Maranao women grow up sheltered and are discouraged to go on a journey alone for the outside world is unknown to them and they can easily get lost. As Saber (1979) said, a Maranao woman is isolated from the complex urban life [26]. She is confined in her homeland without any opportunity to go outside of her world from which she can acquire more knowledge. Once she is out of the confines of her home, she gets exposed to danger. For instance, after getting lost, Potri Gonong Lidang was captured by the tarabosaw reserving her as food for when there would be nothing to eat at all. 


\subsection{Maranao women's means of maintaining balance}

The women characters in the analyzed folktales have learned to surmount their trials and tribulations by maintaining their balance through their ongangen or wisdom or good sense of judgment. The concept of ongangen in the context of maintaining one's balance in the face of adversity is closely similar to the American Indian's (Navajo) idea of the hozho which literally means "walking in beauty"; also maintaining balance.

Tingting a Bolawan when reunited with her parents does not avenge herself against what her aunts did to her and her brothers. She has remained whole and calm despite the physical and emotional hardships she experienced. Upon seeing the kilala plant (planted by her brothers meant to indicate their fate) wilt, she knows that her brothers are in danger. Though she cries the whole night, she does not let her emotions overcome her. When the morning comes, bravely she goes on a journey to save her brothers. Using her wisdom, she is able to free her brothers from their imprisonment in the gindolongan tree, with the other people whose eyes were taken from them and placed in the omoy (earthen vessel).

Yes, our queen, you will see them if you follow our advice. Go around the gindolongan tree seven times then knock on the other side so that the door of the tree will open. Tingting a Bolawan went around seven times and knocked on it and the door opened. She was surprised to find so many people coming out of the tree [27].

The character, Ba'i sa Agamaniyog, in both the stories A Lesson for Sulton and Empty Bogs, Bitter Rice maintains balance by using her ingenuity to endure the emotional pain inflicted by her husband. It is not easy for her to part ways with her husband whom she truly loves, but she never let her emotions overcome her. She puts up a brave front and struggles to make a new life with dignity and determination.

In A Lesson for Sulton, the Ba'i sa Agamaniyog uses her wisdom by thinking of ways to improve Lokes a Mama's condition in life. She told Lokes a Mama to cut down the sandalwood tree, chop it into pieces separating the branches from the trunk and store all the pieces for future use. Not long after, the Sultan of Balantankairan happens to meet Lokes a Mama and asks him if he knows someone in Agamaniyog who has the sandalwood tree. Lokes a Mama tells the Sultan that no one would find such a tree in Agamaniyog except the one he has. The Sultan buys the sandalwood paying with everything he has on his boat, including his seven maids and seven servants. Consequently, the Ba'i sa Agamaniyog and Lokes a Mama become rich and they build a torogan. Soon after, the Ba'i holds a feast to announce to the townspeople that Lokes 
a Mama will be named Maradiya Dinda. All the townspeople witness the affair except the Sultan sa Agamaniyog who has become very poor.

In the same manner, the Ba'i sa Agamaniyog in Empty Bags, Bitter Rice feels the extreme pain of being asked to leave her husband and the Sultan's torogan and go live with Lokes a Mama. With much weeping she leaves the Sultan with the following lines:

Oh! My husband my love! I am now leaving you, but don't forget my words. If I should die, you will have to remember me in the future for having been always faithful to you [28].

Just like in the preceding story, the Ba'i remains stoic and maintains her balance in the midst of her pain using her wisdom in helping Lokes a Mama uplift his financial status. She is determined to be the partner of Lokes a Mama encouraging him to follow what she says to make their life better. And she herself "... wove the ratton into baskets and other things that could be sold in the market. She gave the finished products to the children to sell" [29]. All her efforts have not been in vain. Little by little their savings increase and their life improves.

Similarly, Lokes a Babay, despite having been deceived by Lokes a Mama, is not in a hurry to end their union as husband and wife. She waits for the right time to act on the matter. Confronted with her husband's deception, she remains calm, unbroken, maintaining her balance through her ongangen to prove to Lokes a Mama that she can stand on her own. Eventually, her efforts bring her wealth making her able to build a torogan in a nearby settlement and have guards and slaves to serve her [30].

Lastly, Potri Godong Lidang who has had to contend not only with the pain of separation from her parents for a long time but also with imprisonment by the tarabosaw, remains calm in all her actions. She maintains balance, through her wisdom waiting for the right time to escape from her abductor. When the time finally comes, she acts carefully and wisely so is able to overcome her fear against the tarabosaw. She even instructs Radiya Mangandiri to break the bamboo tube to end the life of the cruel tarabosaw.

The plight of these women characters fits Paula Gunn Allen's (1992) description of the Indian American women:

These women struggle on every front for the survival of their children, their people, their self-respect, their value systems, and their way of life. On their journey of surviving, they continue living and even come to the point of surviving war and conquest, ... starvation, and all sorts of hardships [31]. 
Maranao women, just like other Filipino women are capable of aiming high. They are born achievers but being tied down in their culture makes them lose opportunities to uplift their social status. However, there are those able to break away from the shackles of their culture although they do not totally forget their roots even if they become renowned in their chosen fields. Smith (2011) claims that "deposited in a woman is her will to persevere despite hardships, failures, and disappointments, and to discover in her that hidden treasure that would make her a valuable individual" [32]. This description fits the Maranao woman perfectly as portrayed in the analyzed folktales.

\section{Conclusion and Recommendation}

Despite their patriarchal society, Maranao women can hold esteemed roles whether they are royalty or common people. With maturity age-wise and proven wisdom, these women are consulted by their menfolk about both family matters and community affairs.

But the same patriarchal system confines Maranao women mostly to their homes making their exposure to the larger world very limited, thus, they struggle more than most women when they are thrust outside their homes. Still, the Maranao women are able to deal and overcome their struggles by maintaining their balance through the use of their ongangen. By being so, they remain calm, whole, well-groomed, polite, gentler, and kinder even in the worst of situations. Such balance then allows them to lead positive and, ultimately, successful and/or fulfilled lives.

\section{Author's Note}

Eugenia A. Velasco is a faculty of the English Department, College of Social Sciences and Humanities, Mindanao State University, Marawi City, Philippines. Currently, she is enrolled at Silliman University, Dumaguete City pursuing her Ph.D English (Literary Studies).

Contact No.: $(+63) 9086463085$

Email Address : eanonas@yahoo.com 


\section{References}

[1] McAmis, Robert Day. (1966). An Introduction to The Folktales of the Maranao Muslims of Mindanao in the Southern Philippines. Philippine Studies Program, Department of Anthropology, University of Chicago, p.4.

[2] Madale, Abdullah T. (1976). The Remarkable Maranaws. Quezon City: Omar Publications, p.1.

[3] Drake, Robert. "Hozho: Dine' Concept of Balance and Beauty", http: //oceansoulrenewal.us, March 14, 2017.

[4] Lincoln, Kenneth. (2007). Speak Like Singing Classics of Native American Literature. Albuquerque: University of Mexico Press, p.102.

[5] Allen, Paula Gunn. (1992). The Sacred Hoop: Recovering the Feminine in American Indian Traditions. U.S.A.: Open Road Media, p.19o.

[6] p.191.

[7] Smith, Naomi Hafford. (2011). A Woman's Worth...from Broken Promise to Fulfilled Prophecy. Inidana: WestBow Press.

[8] Bressler, Charles E. (2007). LITERARY CRITICISM An Introduction to Theory and Practice. $4^{\text {th }}$ Edition. Indiana: Pearson, p.181.

[9] Carlos, Abigeil F. and Jovy Cuadra F. (2014). Migrant Muslim Women's Resiliency in Coping With the Traditional Family Practices, Journal of Education and Social Sciences, Vol. 7, Issue 1, (June) 2017 ISSN 2289-1552, p.59. Retrieved from https: //jesoc.com

[10]

[11] Rogers, Linda Peterson. (2000). Women Recreating Their Lives: Challenges and Resilience in Midlife, Dissertation, Virginia Polytechnic Institute and State University, Retrieved from https://theses.lib.vt.edu>unrestricted>etd

[12] Saber, Mamitua (1979). "Introduction", The Maranao Woman. Mindanao Art \& Culture no.2, Marawi City: University Research Center, Mindanao State University, p.3.

[13] Manalisig, Bolawan B. (1979). "Coronation of a Ba'i a Labi". The Maranao Woman. Mindanao Art \& Culture Number 2, Marawi City: University Research Center, Mindanao State University, p.33.

[14] The Agamaniyog Folktales. Mindanao Art and Culture, Number 1, Marawi City: University Research Center, Mindanao State University, p.82. 
[15] Saber, Mamitua (1979). "Introduction", The Maranao Woman. Mindanao Art \& Culture Number 2, Marawi City: University Research Center, Mindanao State University, P.3.

[16] The Agamaniyog Folktales. Mindanao Art and Culture, Number 1, Marawi City: University Research Center, Mindanao State University, p.16.

[17] _ P.55.

[18] _ _ 76.

[19] Saber, Mamitua (1979). "Introduction", The Maranao Woman. Mindanao Art \& Culture Number 2, Marawi City: University Research Center, Mindanao State University, p.3.

[20] The Agamaniyog Folktales. Mindanao Art and Culture, Number 1, Marawi City: University Research Center, Mindanao State University, p.76.

[21] Plawan, Hadja Maimona Aida L. (1979). The Maranao Woman. Mindanao Art \& Culture Number 2, Marawi City: University Research Center, Mindanao State University, p.4.

[22] _ P.4.

[23] The Agamaniyog Folktales. Mindanao Art and Culture, Number 1, Marawi City: University Research Center, Mindanao State University, p.76.

[24] p.81.

[25] - P.53.

[26] Saber, Mamitua (1979). "Introduction", The Maranao Woman. Mindanao Art \& Culture Number 2, Marawi City: University Research Center, Mindanao State University, p.3.

[27] The Agamaniyog Folktales. Mindanao Art and Culture, Number 1, Marawi City: University Research Center, Mindanao State University, p.14.

[28] p.81.

[29] p.81.

[30] P.76.

[31] Allen, Paula Gunn. (1992). The Sacred Hoop: Recovering the Feminine in American Indian Traditions. U.S.A.: Open Road Media, p.19o.

[32] Smith, Naomi Hafford. (2011). A Woman's Worth...from Broken Promise to Fulfilled Prophecy. Inidana: WestBow Press. 